\title{
China's Rising Household Debt: A New Debt Trap?
}

\section{Sarah Chan*}

\section{Summary}

Household debt in China has risen rapidly in recent years, mostly driven by mortgages but also by ongoing financial deepening and liberalisation which facilitate economic rebalancing towards more consumption. Although the risks to financial stability do not seem large at the time of writing, the sharp rise in household debt has raised some concerns, as high household borrowing could increase macro-financial risks, particularly given the US-China trade tensions and the ongoing coronavirus pandemic that has resulted in weaker employment and export market. Rising household debt will add to medium- to long-term challenges for China's domestic consumption and the financial sector. The authorities have so far implemented measures to lessen the risk of a sharp housing correction in the short-run.

Keywords: Household debt, credit, financial stability, China

JEL: D10, D14, E21, G21, G51

\section{Introduction}

Jousehold debt in China has been expanding rapidly since the global financial crisis. According to data from the Bank for International Settlements (BIS), as of end-2018, the total debt of Chinese households stood at $52.6 \%$ of GDP, above the emerging market average (of $40 \%$ ), and 32 percentage points of GDP higher than in 2008. Part of the rise in household leverage reflects financial deepening and development, which, combined with rising incomes, facilitates more widespread access to credit as a result of improved financial inclusion.

The speed with which households ${ }^{1}$ have accumulated leverage has raised concerns whether further debt increases could adversely affect growth and financial stability. Fitch Ratings warned that the rapid pace of household debt growth in China is more of a concern than its level. ${ }^{2}$ The People's Bank of China (PBOC) similarly warned that the figure of $60.4 \%$ at end-2018 is much higher than the average of emerging market economies (EMEs), even though the overall risks are still controllable and the bad loan ratio for household loans is still low. ${ }^{3}$

\footnotetext{
"East Asian Institute, National University of Singapore.

${ }^{1}$ According to China's System of National Accounts, household sector in China refers to the aggregation of urban and rural households, and individual businesses.

${ }^{2}$ In a report released in July 2019, Fitch wrote that "should China's gap with international peers effectively close in the next two to three years, this would add considerably to the country's overall macroeconomic vulnerabilities, given the corporate debt burden that is already among the world's largest by most measures."

${ }^{3}$ Refer to PBOC, China Financial Stability Report, 2019.
} 


\section{Articles}

The sharp rise in household debt in China suggests that the risks facing households and the financial system have increased, as household indebtedness could constrain future consumption growth and increase financial stability risks. Cross-country studies (Mian et al., 2013; Jorda et al., 2016) indicate that higher household debt could increase consumption and GDP growth in the short term but reduce them in the longer term. The negative long-run effects are intensified when household debt-to-GDP ratio exceeds the 60\% threshold (Lombardi et al., 2017).

Some studies also found that high household debt has been associated with lower consumption growth. The income elasticity of consumption is significantly higher in households with high levels of debt; as such, when facing a negative income shock, households with higher debt consume relatively less as they are more sensitive to income fluctuations (Nakajima, 2018; Baker, 2014).

Higher household debt could also increase the probability of banking distress and financial stability risks. With high indebtedness, households are more vulnerable to adverse shocks which could force them to deleverage abruptly, particularly given that more than half of the household debt in China comprises mortgages. As economic growth slows, the vulnerability of high household indebtedness is likely to amplify the impact of adverse income shocks on debt repayment capacity and hence household defaults, causing deterioration in the quality of bank asset loans.

Overall, the risks are contained despite the buildup in household debt. Loans to households in China are still a smaller fraction of banks' total assets than in advanced economies (IMF, 2017). Household balance sheets are still healthy with robust savings.
Financial regulators have also moved to tighten supervision of consumer lending amid growing concerns about the surge in household debt. For instance, multiple rounds of tough crackdowns have been launched on P2P lending platforms in 2018 while the authorities have forced banks to tighten their lending standards by imposing sale and purchase restrictions in a large number of Chinese cities in recent years, particularly for second and third dwellings. ${ }^{4}$

To date, there are not many studies on China's household debt as there is no accurate data on household indebtedness (like local government debt). There are also idiosyncratic differences between the composition of household debt in China and other economies, which makes international comparison and assessment difficult. For instance, China includes in its household debt operating loans to small businesses due to their family-run nature, whereas this item usually comes under business loans in other economies. This complicates the international assessment of China's household sector risk.

This paper attempts to bridge the gap by summarizing the current state of understanding in this area and drawing on the micro-level household survey data as well as macro-level national statistics to analyse the trends of household debt and its resultant implications. Examining the household balance sheet is useful in assessing the financial soundness and risk of the household sector. The China Household Finance Survey (a national representative survey), for instance, provides an insight into the structure of household financing. This article aims to supplement the discussion on China's household debt sustainability at the macro level with analyses of household survey results (at the microlevel) since aggregate data cannot account

\footnotetext{
${ }^{4}$ China has changed its policy stance since 2018 on household leverage from encouraging to discouraging its growth. The banking regulators have asked banks to cut lending to households since 2018 . This is a policy reversal from the PBOC's encouragement to boost household lending, especially in mortgages, in 2016. It has implemented restrictive policies to curb housing speculation through very high $(50 \%+)$ down-payment and caps on debt serviceto-income ratio of less than $50 \%$ to discourage household borrowing.
} 


\section{Articles}

for differences in income and debt distribution among various groups in the population.

The remainder of this paper is organised as follows. The second section discusses the trends in China's household debt and what drives households' indebtedness. The third section evaluates the macro-financial risks emanating from the household sector while the fourth section discusses the author's observations and thoughts on the issue, including the impact of the coronavirus outbreak on household indebtedness. The final section concludes with relevant policy implication and recommendations.

\section{How Worrying is China's Household Debt?}

Household debt in China has grown at an average annual rate of more than $20 \%$ over the past decade (2008-2018). As a result, the ratio of household debt to GDP increased sharply, from around $20 \%$ in 2009 to $53 \%$ in 2018. This ratio is comparatively lower than in most advanced countries (for instance, the G20 average of $59 \%$ ) but higher than many emerging market economies - of $40 \%$ (Chart 1). The pace of growth is particularly rapid when compared to the EMEs and China's regional neighbours like Malaysia and Korea.

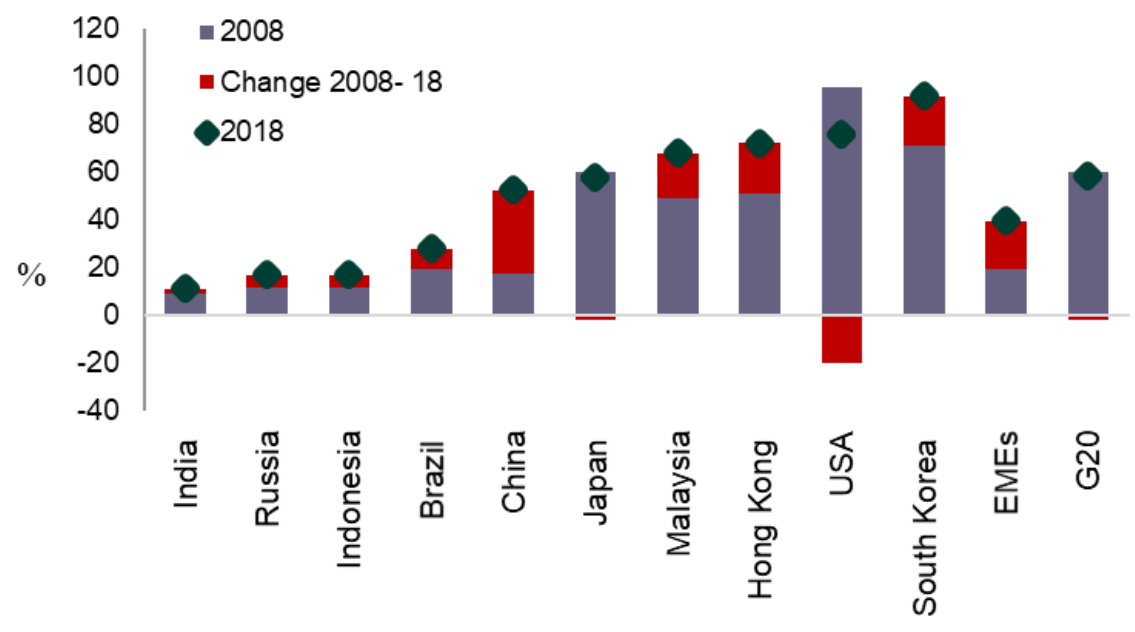

Chart 1: International Comparison of Household Debt-to-GDP Ratio

Source: Bank for International Settlements.

The speed of growth in China's debt is also rapid when using the ratio of household debt to income as a measure of debt risk. Chart 2 shows that China's household debt to disposable income ratio doubled from $40 \%$ in 2009 to around $85-90 \%$ in $2018 .{ }^{5}$ The PBOC reported China's debt to income ratio to be $100 \%$ in 2018 whereas another estimate, using survey data by the National Bureau of
Statistics (NBS), was $121 \%$ which was higher than some developed countries like the US (99\%), Germany (86\%), Belgium (106\%) and Japan $(103 \%, 2017)$ but comparable to the UK (133\%). The ratio appears alarmingly high as the denominator is calculated using the disposable income in household survey data collated by the NBS. Due to the process of data collection, residents may conceal

${ }^{5}$ Fitch Ratings' estimate is $85 \%$ while the authors of the joint report released by CHFS and Ant Financial Group on "China Household Leverage Ratio and Consumer Credit Usage" estimate the ratio to be $90 \%$. 
or misreport their real income owing to tax | evasion and this leads to an overestimation of the household debt-to-income ratio.

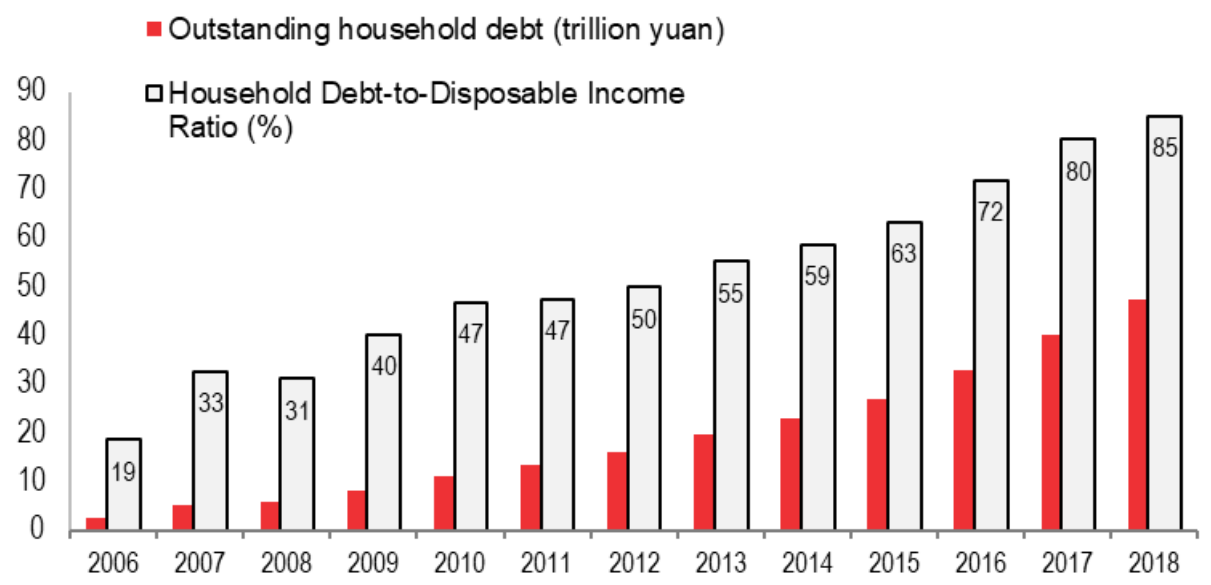

Chart 2: Household Debt in China

Source: CEIC and Bank for International Settlements. Note: Household debt-to-income ratio estimate for 2018 by Fitch Ratings.

Using total disposable income data for the household sector in the flow of funds statement that is found in the National System of Accounts, China's household debt-toincome ratio of $90 \%$ in 2018 is lower than that of some advanced economies like the US, UK and Japan but comparable to Germany, Chile (73\%), Italy (80\%) and Austria (85\%).

Incidentally, a joint report released by the China Household Finance Survey and Research Center (an academic institution established by SouthWestern University of Finance and Law) and Ant Financial Group revealed a discrepancy when calculating China's household debt risk. In 2018, the total disposable income of residents derived from the funds of the national economic accounting system was 57.7 trillion yuan while the data of household survey collated by the NBS was 39.4 trillion yuan, with a difference of 18.3 trillion yuan (Table 1). In other words, the per capita disposable income is underestimated by 13,000 yuan, suggesting that China's household debt-to-disposable income ratio (using survey data) may be higher than is widely perceived.

Table 1. Differences in Household Disposable Income Reported by Various Sources

\begin{tabular}{|l|l|l|l|l|}
\hline & $\begin{array}{l}\text { Household Disposable Income (in } \\
\text { trillion yuan) reported by National } \\
\text { Bureau of Statistics (NBS) }\end{array}$ & $\begin{array}{l}\text { Household Income (in } \\
\text { trillion yuan) from Flow of } \\
\text { Funds (FoF) data }\end{array}$ & $\begin{array}{l}\text { Household debt-to- } \\
\text { disposable income ratio, \% } \\
\text { (NBS) }\end{array}$ & $\begin{array}{l}\text { Household debt-to- } \\
\text { disposable income ratio, \% } \\
\text { (FoF) }\end{array}$ \\
\hline 2013 & 24.9 & 35.7 & 79.7 & 55.6 \\
\hline 2014 & 27.6 & 39.1 & 83.9 & 59.2 \\
\hline 2015 & 30.2 & 42.3 & 89.5 & 64.0 \\
\hline 2016 & 32.9 & 45.6 & 101.3 & 73.1 \\
\hline 2017 & 36.1 & 49.3 & 112.2 & 82.2 \\
\hline 2018 & 39.4 & 57.7 & 121.6 & 90.2 \\
\hline
\end{tabular}

Source: CHFS survey. 


\section{Articles}

Note: Relying on a mix of CHFS and NBS data, the authors of the report factor in transfer income sources that the NBS does not include, such as workers' compensation and subsidies to farmers, for instance. The National System of Accounts that the NBS relies on for its data also uses an accrual-based accounting method, whereas the authors of the report use a cash-based method which can also contribute to reporting discrepancies. The authors note their methodology is more similar to the way OECD countries calculate household debt-to-income ratios.

The increase in household debt underscores the strong policy support in the past few years as part of financial liberalisation to facilitate economic rebalancing towards more consumption. It reflects the rapid process of financial deepening following reforms that were in part designed to increase household consumption as a share of economic activity in China. These included the privatisation of the housing stock and introduction of mortgages in the 1990s and the ongoing financial deregulation (RBA, 2019). The increase in household income and the decline in interest rates in China over the 2010s have also increased households' ability to service debt. ${ }^{6}$
Further, the deleveraging campaign launched in late 2016 redirected banks' incentives to lend to households rather than companies. Following the regulatory crackdowns on shady financing instruments that had previously delivered high returns, banks' net interest margins were reduced, the result of which was to encourage banks to lend more to households since mortgage interest rates were higher than corporate lending rates particularly on loans to stateowned enterprises and local government financing vehicles (Rhodium Group, 2020).

Mortgage debt has been the biggest driver of the increase in household debt over the past decade and now accounts for more than half of China's household debt. ${ }^{7}$ By end-2019, housing-related debt accounted for $55 \%$ of household's total debt (Chart 3 ). This has been largely owing to the booming property market and better access to credit by households. Housing loans for second and third homes have also increased rapidly. In 2018, 66\% of housing loans financed the purchase of a second or third home. This is in contrast to 2011 where fewer than $30 \%$ of home loans were used to pay for a second or third home. ${ }^{8}$

\footnotetext{
6 Ibid.

7 Between 2013 and 2019, mortgages accounted for half (51\%) of China's household debts.

8 Joint Report on "China Household Leverage Ratio and Consumer Credit Usage" by Survey and Research Center for China Household Finance at the Southwestern University of Finance and Economics and Ant Financial Group. Article available at https://chfs.swufe.edu.cn/thinktank/resultsreport.html?id=2380. (accessed 2 February 2020). The authors conduct survey on nearly 40,000 households in 29 provinces in China, excluding Tibet.
} 


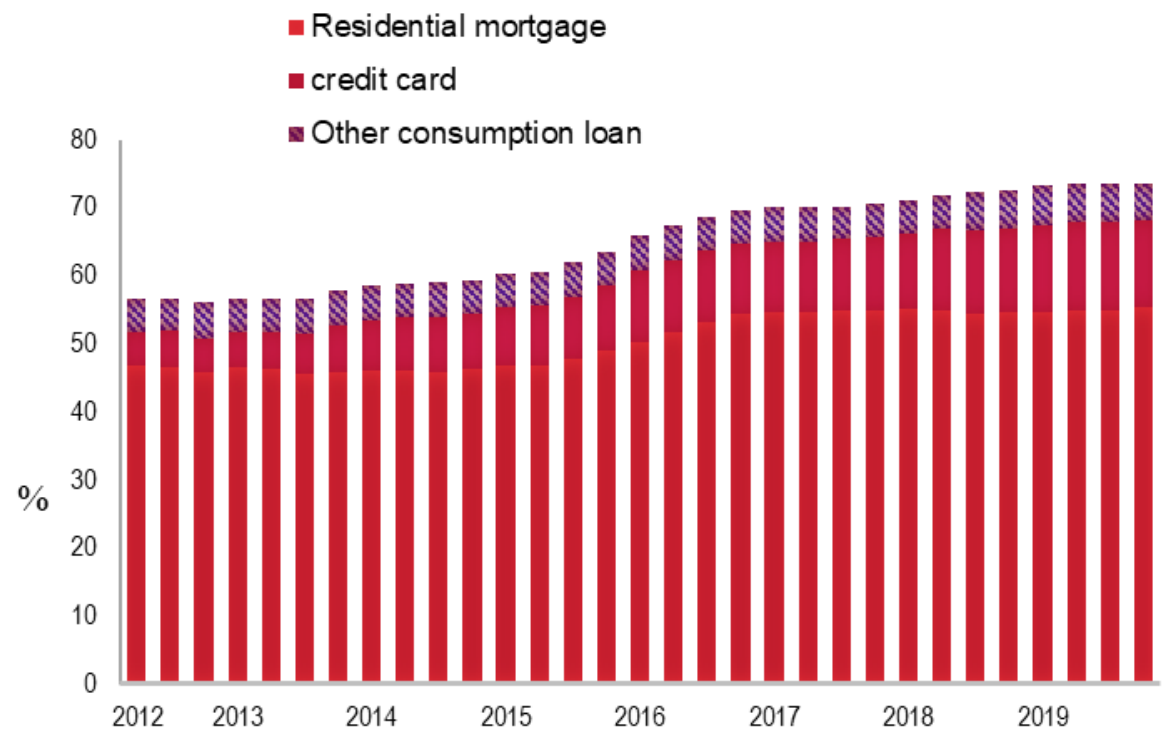

Chart 3: Components of Household Borrowing in China

Source: CEIC

While much of China's household debt has been led by property-related borrowing, consumption borrowing via auto financing and credit card facilities has seen rapid increase too (Chart 4). Card debt has risen strongly, with such debt experiencing a seven-fold surge in total household borrowing from $2 \%$ in 2009 to
$15 \%$ in 2018. Such consumer credit access has been vital for supporting consumption since it allows the households to tap into their "expected future earnings or income", hence enhancing their current spending power via inter-temporal spending.

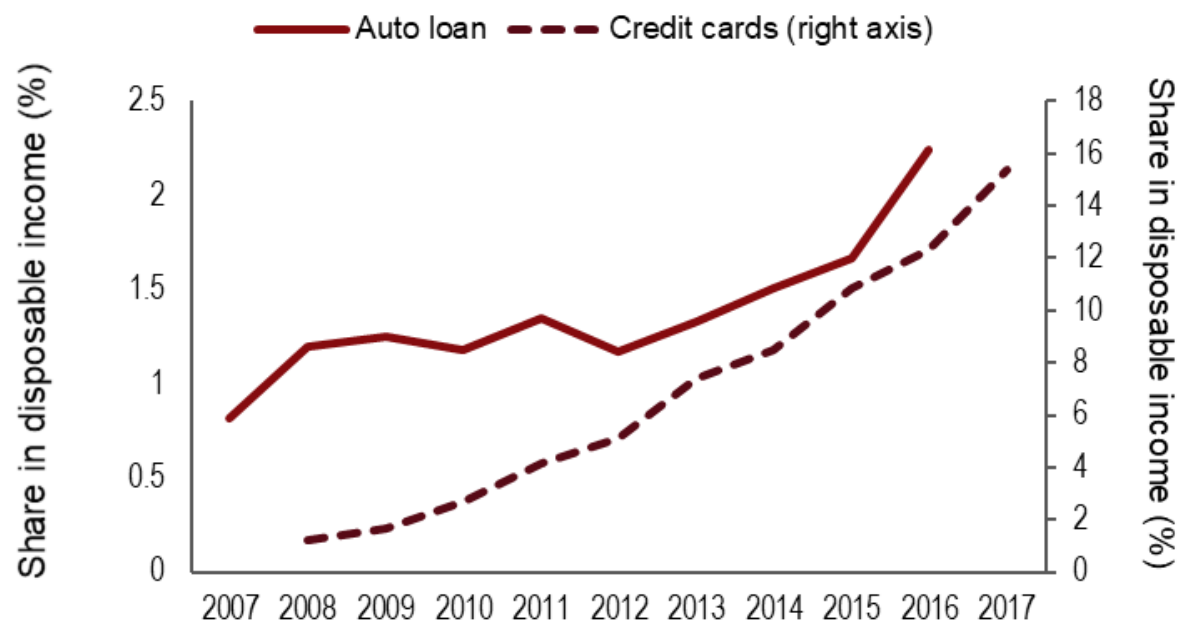

Chart 4: China: Auto Loans and Credit Cards

Source: CEIC 


\section{Articles}

The aggregate debt-to-GDP ratios may well hide significant differences among China's regions. Household indebtedness varies significantly across regions and is unevenly distributed among provinces. In 2018, provinces with a household leverage ratio above the national average include Zhejiang (84\%), Shanghai (83\%), Beijing (72\%), Guangdong (71\%), Gansu (70\%), Chongqing (69\%), Fujian (66\%) and Jiangxi (63\%). The difference was as large as 50 percentage points between the highest Zhejiang province and the lowest Shanxi province. Among those provinces, the household debt-toincome ratios of Zhejiang, Shanghai, Beijing, Guangdong, Fujian and Chongqing were also above the national average, indicating heavy household indebtedness (PBOC, 2019).

The aggregate debt-to-GDP ratios may also mask significant differences between household types. Low income groups are found to have very high debt burdens. According to the China Family Panel Studies conducted by the Peking University in 2016, debt burdens on low-income families were generally heavier than those on high-income families. For indebted families, the average debt-to-income ratio of families with an annual income of less than 60000 yuan (US\$ 8,460 ) was $286 \%$ while that of families with an annual income of more than 360000 yuan (US\$ 50,780) was 89\%.'

Low-income families, with limited financial assets and inelastic spending on essentials, are therefore easily vulnerable to worsening financial conditions. They also tend to rely heavily on non-bank sources of credit compared to high-income groups. According to a joint report released by the China Household Finance Survey and Ant Financial Group, nearly $75 \%$ of low-income earners debt came from non-bank sources of credit, whereas non-bank sources of credit accounted for $26 \%$ of high-income earners' debt. The main non-bank entities providing credit are consumer finance companies, auto finance firms and online lenders. They offer low-income groups, which have generally been overlooked by traditional financial service providers, more opportunities to gain access to credit. While some of the non-bank lenders are subject to regulatory control, most online lenders (including P2P lending platforms), are actually not licenced and could pose credit risks when they lend indiscriminately to households and individuals. ${ }^{10}$ Growth in these riskier types of household debt not measured in official household debt statistics, has been particularly strong in the past few years, although it has slowed recently after the Chinese authorities tightened regulation of this lending.

Further, a recent survey ${ }^{11}$ published by the People's Bank of China revealed that middle-class wage earners, young mortgage holders and small business owners faced the greatest risks from household indebtedness. According to the survey which looked at 30,000 households nationwide in October 2019 and their balance sheets, property accounted for $59 \%$ of household assets (a higher proportion than in the United States) and three quarters of liabilities with the average family having a mortgage of 389,000

\footnotetext{
${ }^{9}$ Additionally, of the families earning less than 60000 yuan annually, $0.8 \%$ of them owed debts larger than 500 000 yuan, which means that it will take nearly a decade for them to repay debts with all their income on condition that there are no changes to their income levels. Refer to source in Footnote 3.

${ }^{10}$ For example, they provided a way around loan-to-value requirements by allowing households with insufficient savings to also finance the down payments of consumer items.

11 The survey results were released by China Finance, a magazine affiliated to the central bank. It was the first national survey gauging the scale of household debt released to the public by the PBOC in recent years.
} 
yuan (US\$ 54,860). Households may have difficulty meeting their financial obligations as only $20 \%$ of the assets these households held were financial assets, which means it is difficult for them to turn them into liquid assets in times of emergency.

\section{Risks from Rising Household Debt}

Higher household borrowing could increase macroeconomic risks. Empirical cross-country studies (Mian et al., 2017; Jorda, 2016) have found that higher household debt may lead to lower GDP growth. Higher debt repayments could weaken aggregate demand by constraining future consumption growth and property investment (Chart 5). Real estate investment may be affected as housing demand slows, property developers face funding pressures, and banks are more reluctant to lend due to higher household credit risk. Lower fiscal revenues and public support of home ownership also create risks for the fiscal sector. These in turn could contribute to excess savings and growing external imbalances (Fei Han et al., 2019).

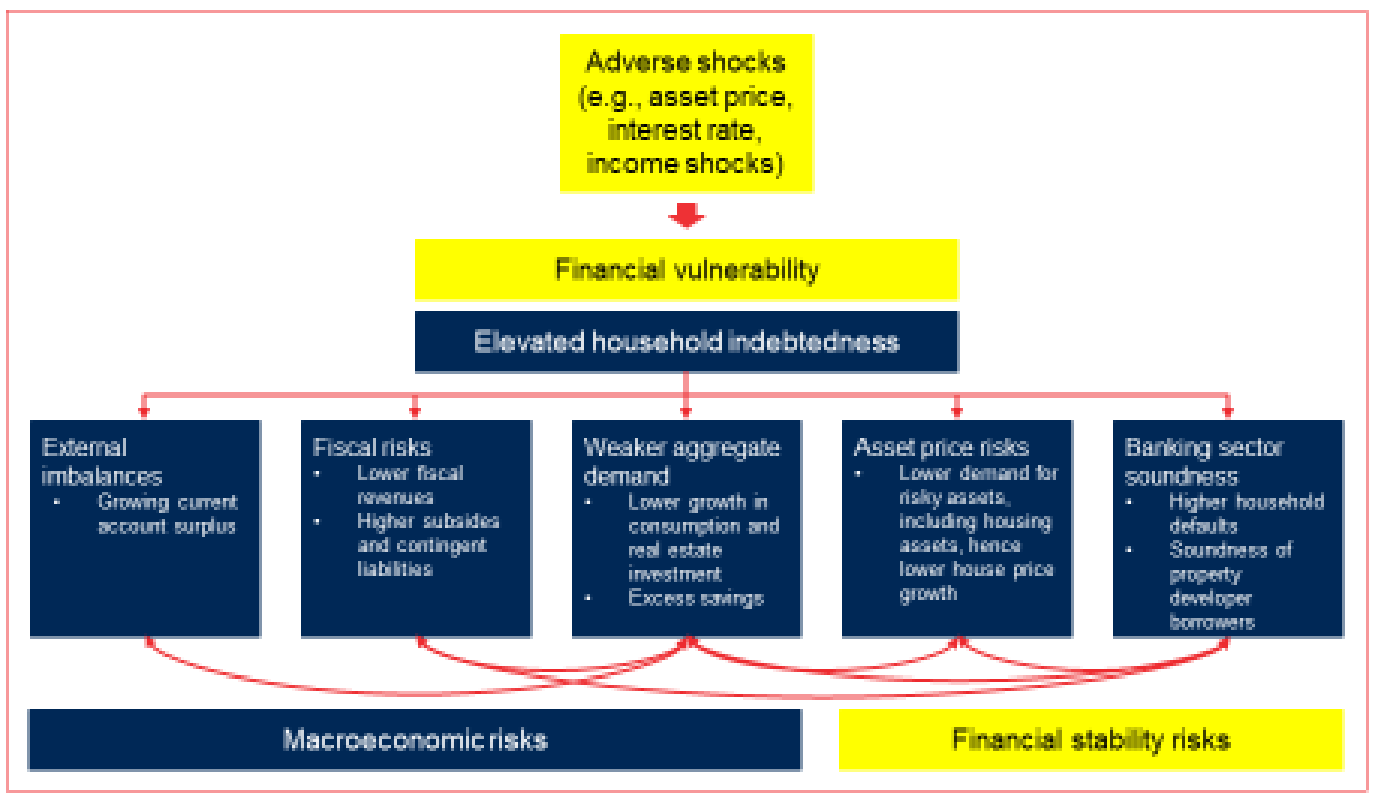

Chart 5: Macro-Financial Risks from Elevated Household Debt Indebtedness Source: IMF

Financial stability risks may also be heightened through increasing household debt, since households that are more indebted are more vulnerable to adverse shocks, which in turn may force them to deleverage abruptly. This could lead to a significant macro-financial impact. As mortgages make up more than half of household debt in China, deleveraging could constrain housing demand growth and consequently put pressure on house price growth, and affect the financial soundness of property developers.

Severe house price corrections could further reduce banks' financial soundness, as the collateral on their real estate loans would have a lower value, as well as increasing 


\section{Articles}

funding pressure for property developers, further increasing banks' risk aversion to lend. Consequently, higher household debt may increase the probability of banking distress, and worsen any subsequent recessions, as research shows that recessions preceded by housing busts are longer and more severe. A housing crash or significant declines in property prices could also put financial pressure on local governments, which are reliant on property-related taxes and land sales as sources of revenue.

\section{Discussion}

While the risk of a systemic crisis is not imminent at the moment, there are indications that household debt may further rise and amplify household default risk amid rising unemployment due to the trade tensions with the US as well as the looming global recession brought about by the ongoing coronavirus pandemic. Weaker employment and income growth, resulting from a worsening job and export market, have begun to lead to rising defaults in mortgages, credit cards and overall household debt in China. There are indications that delinquencies on credit-card debt, mortgages and micro loans have increased; for instance, Qudian Inc., a
Beijing-based online lender, reported that its delinquency ratio jumped to $20 \%$ in February 2020 from $10 \%$ in $3 Q 2019 .^{12}$ As more than 10 million jobs are estimated to be at risk ${ }^{13}$, households may have difficulty servicing their loans and this may have an adverse impact on household indebtedness even if private consumption is expected to decline as economic growth slows and uncertainties increase.

On the whole, risks appear contained at the moment despite rising household debt. In China, lending to households is mainly facilitated by banks. Household credit has risen strongly as a share of banking assets but overall loans to households in China are still a smaller fraction (18\%) of banks' total assets than in advanced economies. ${ }^{14}$

Further, the risk of household debt to the banking system is manageable. In terms of non-performing loan (NPL) ratio, the quality of household loans is better than other loans. As at end-2017 (latest data available), the NPL ratio for credit cards and home mortgages was only $1.6 \%$ and $0.3 \%$ respectively, lower than the banks' overall NPL ratio of $1.74 \%$ (Chart 6). Households seem able to meet their financial obligations and the risk of household debt to the banking system is limited.

\footnotetext{
${ }_{12}$ About $30 \%$ of Chinese households may not be able to service their debt if they have no income for one month. The debt servicing cost for an average Chinese household is thought to be over $30 \%$ of its disposable income. Refer to S\&P Global, "Chinese banks seen withstanding rising household defaults", 15 April 2020 (accessed 6 May 2020).

${ }_{13}$ The outlook for the labour market is not optimistic, with UBS forecasting the worst job market for China in more than two decades. Refer to Bloomberg, "China Faces Worst Job Market in 20 Years as Growth Slumps: UBS", 8 April 2020.

${ }^{14}$ Calculations from CEIC data.
} 


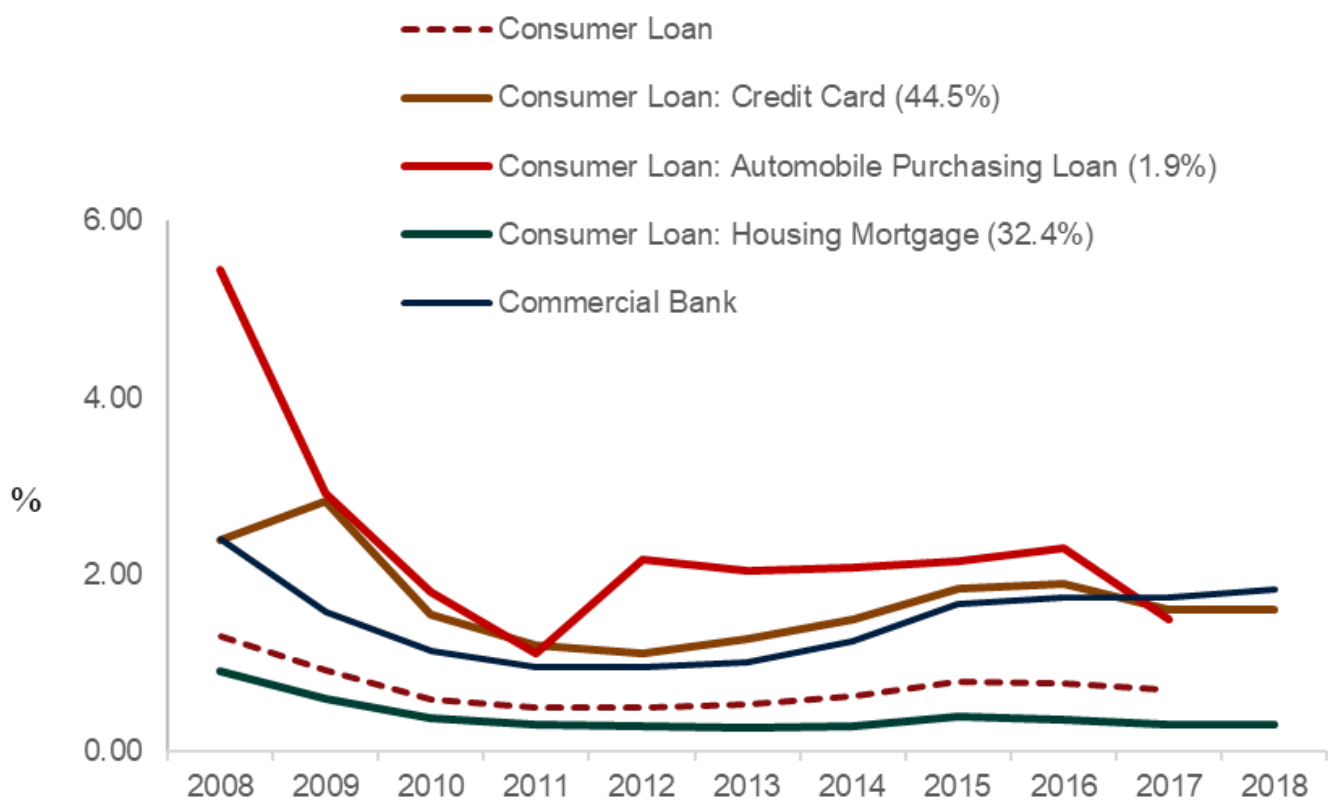

Chart 6: NPL Ratio by Household Loans

Note: The number in parenthese after each loan is the share of NPLs in total NPL. Source: CEIC.

On the whole, the balance sheets of China's households are relatively healthy. An imminent insolvency risk for Chinese households seems unlikely, given that the liabilities-to-assets ratio of $9.2 \%$ is lower than those in economies like the US (12.8\%), Australia (18\%), Japan (17.4\%), Canada $(16.8 \%)$ or Italy $(17.2 \%) .{ }^{15}$ China's household income has continued to rise, making debt manageable but debt repayments could worsen amid a slowdown in economic growth. Although the debt burden of mortgage borrowers in urban areas has increased in recent years, the mortgage loan participation rates are still relatively low compared with advanced economies (IMF, 2017).

Although household debt risks remain controllable, the authorities should continue their macro-prudential supervision by subjecting household borrowing to stringent credit standards. They should also closely monitor rising property prices as well as low income households which generally have lower repayment capacity. This is particularly so given that household debt is now the second largest type of debt in China (following corporate debt) and household borrowing has increased considerably in recent years with important implications.

\section{Conclusion and Recommendation}

International experience suggests that high levels of household debt can amplify income and wealth shocks. In response to negative shocks, indebted households can cut back discretionary spending more than non-indebted households. To mitigate the risks associated with increasing household debt, the growth of household debt should be closely monitored with the use of macro-prudential measures to

${ }^{15}$ Except for China (2016), the figures for other countries is 2018. Author's calculations from CEIC database. 


\section{Articles}

curb speculative activities in the real estate market and prevent over-borrowing of credit to fund housing purchases. ${ }^{16}$ In this regard, reforms to enhance financial deepening and measures to develop the bond and securities markets to offer households more liquid financial instruments for risk diversification are important, as this will help to mitigate the overdependence of household wealth on dwellings/property.

Stringent credit standards should also be in place. Even though the overall debt burden is not high and repayment capacity is generally not a problem yet, more stringent credit standards should be adopted when issuing household loans, to ensure that the borrowers (particularly low-income group) have the capacity to repay the loans. The authorities should further regulate and monitor the use of personal loans, and strictly prohibit households from using personal loans to finance home purchase as it will create a maturity mismatch problem. The government has so far adopted a variety of tools, ranging from loan-to-value ratio caps on restrictions on purchases or resales. This lessens the risk of a sharp housing correction in the short-run.

The risks emanating from the rise in household debt in China call for close monitoring. Rising household debt will add to medium- to long-term challenges for domestic consumption and the financial sector. Going forward, the government would need to manage the risks between promoting consumption and averting potential financial distress, particularly given that economic growth is slowing both structurally and cyclically with ongoing structural transformation and weak external demand.

\section{References}

Baker, S. R. (2014): "Debt and the Consumption Response to Household Income Shocks," Mimeo, Stanford University.

Fei Han, Emilia Jurzyk, Wei Guo, Yun He and Nadia Rendak, 2019. Assessing MacroFinancial Risks of Household Debt in China, IMF Working Paper WP/19/258, November 2019.

Fitch Ratings, Household Debt in China. July 2019.

Funke, M., Sun, R., and L. Zhu, 2018, "The Credit Risk of Chinese Households - A MicroLevel Assessment," BOFIT Discussion Paper No. $12 / 2018$.

Jorda, O., Schularick, M., and A.M. Taylor, 2016. The Great Mortgaging: Housing Finance, Crises and Business Cycles. Economic Policy 31 (85), pp.

Lombardi, M., Mohanty, M., and I. Shim, 2017, "The Real Effects of Household Debt in the Short and Long Run," BIS Working Paper No. 607, Bank for International Settlements, Basel.

Nakajima J., 2018. The Role of Household Debt Heterogeneity on Consumption: Evidence from Japanese Household Data. BIS Working Paper No. 736, 2018.

International Monetary Fund (IMF), October 2017. Global Financial Stability Report: Is Growth at Risk? Available at <https://www.imf. org/en/Publications/GFSR/Issues/2017/09/27/ global-financial-stability-report-october-2017> (accessed 20 January 2020)

Mian, A., Sufi, A., and E. Verner, 2017. Household Debt and Business Cycles Worldwide. The Quarterly Journal of Economics 132(4), pp. 1755-1817.

\footnotetext{
${ }^{16}$ Nearly two-thirds of outstanding mortgage debt in 2018 was owed by families which already owned more than one property. Refer to source in Footnote 8.
} 
Mian, A., K. Rao, and Sufi A., 2013. Household Balance Sheets, Consumption, and the Economic Slump. The Quarterly Journal of Economics, 128(4), pp. 1687-1726.

People's Bank of China (PBOC), 2019. China Financial Stability Report, 2019.

Reserve Bank of Australia (RBA), 2019. "Household Sector Risks in China", Financial Stability Review. Article available at < https:// www.rba.gov.au/publications/fsr/2019/oct/ box-a-household-sector-risks-in-china. $\mathrm{html}>$ (accessed 4 January 2020).
Rhodium Group, "Covid-19 and China's Household Debt Dilemma", 12 May 2020

Joint Report on "China Household Leverage Ratio and Consumer Credit Usage" by Survey and Research Center for China Household Finance at the Southwestern University of Finance and Economics and Ant Financial Group.

Article available at <https://chfs.swufe.edu. $\mathrm{cn} /$ thinktank/resultsreport.html?id=2380> (accessed 9 February 2020). 